\title{
Florida Turkey Nest Site Selection and Success
}

\author{
William M. Giuliano*, Lauren N. Watine, John M. Olson, Mitchell Blake, Holly Ober \\ Department of Wildlife Ecology and Conservation, University of Florida, Gainesville, USA \\ Email: *docg@ufl.edu
}

How to cite this paper: Giuliano, W.M., Watine, L.N., Olson, J.M., Blake, M. and Ober, H. (2016) Florida Turkey Nest Site Selection and Success. Natural Resources, 7, 644-654.

http://dx.doi.org/10.4236/nr.2016.711051

Received: July 22, 2016

Accepted: November 20, 2016

Published: November 23, 2016

Copyright $\odot 2016$ by authors and Scientific Research Publishing Inc. This work is licensed under the Creative Commons Attribution International License (CC BY 4.0).

http://creativecommons.org/licenses/by/4.0/

\begin{abstract}
Changing landscapes and land-use practices are altering habitat for Florida wild turkeys (Meleagris gallopavo osceola). However, an understanding of habitat determinants of nest success is lacking for this unique turkey subspecies, potentially limiting conservation success. We examined female wild turkey nest site selection and nest success at microhabitat and patch levels using logistic regression in an InformationTheoretical framework in Florida, 2008-2010. We captured and radio-equipped adult female turkeys, and followed birds to nests. Nests were monitored to document success, and habitat was measured at multiple levels at nest and random sites. Females selected nest sites in dense vegetation (i.e., increased saw palmetto cover [Serenoa repens] and higher palm stem densities) that may have provided lateral and vertical cover for concealment at the microhabitat level (i.e., area within $7 \mathrm{~m}$ of the nest), while selecting for a more open habitat (i.e., decreasing hardwood and conifer stem densities) at the patch level (i.e., area within $28 \mathrm{~m}$ of the nest). Similarly, successful nests were in more dense vegetation at the nest site (i.e., increased saw palmetto cover) in an otherwise more open habitat (i.e., lower basal area) than unsuccessful nests. Habitat management that creates patches of dense shrub vegetation such as saw palmetto within an open landscape may be best for Florida wild turkey nesting habitat and success.
\end{abstract}

\section{Keywords}

Florida, Nest, Selection, Success, Turkey

\section{Introduction}

Very little is known about nest habitat selection and its effects on nest success of the unique Florida wild turkey (Meleagris gallopavo osceola). With changing land-use practices degrading or destroying native habitats through urban development, road construction, fragmentation, conversion to agriculture, fire exclusion, invasive species, and changes in natural disturbance regimes [1] [2], this lack of understanding may limit 
Florida turkey conservation success.

Anecdotal evidence suggests that female Florida wild turkeys select areas in transition zones between palmetto prairie and oak scrub [3], saw palmetto ecotones [4], and dense vegetation [5] for nesting. Habitat often drives nest success, habitat selection is a hierarchical process where birds select features at different scales [6] [7] [8], and nest success may be the most important factor affecting wild turkey population growth and size [9] [10]. Therefore, to better manage the unique Florida wild turkey subspecies, further information is needed to understand habitat determinants of nest success. Our objectives were to understand how nest site characteristics influence female turkey nest site selection at two spatial scales and evaluate how nest site selection relates to success.

\section{Materials and Methods}

\subsection{Study Area}

We conducted the study on two sites in south Florida from 2008-2010, representing typical public and private lands turkey habitat in the region. The first site was the 6273 ha Quail Enhancement Area of Three Lakes Wildlife Management Area (WMA), located in Osceola County, Florida. Three Lakes WMA consisted primarily of pine flatwoods, with lesser amounts of intermingled hammocks, swamps, and wet and dry prairies [11]. Three Lakes WMA is managed by the Florida Fish and Wildlife Conservation Commission (FWC) and hunting is allowed for most game species, including wild turkey.

The second site was Longino Ranch, located in Sarasota County, Florida. Longino Ranch encompasses approximately 4040 ha, with 2020 ha used for the production of cattle, sod, and citrus. The remaining 2020 ha were primarily pine flatwoods, with lesser amounts of intermingled wet and dry prairies and oak-cabbage palm hammocks [11]. The ranch allows hunting by the owners of most game species, including wild turkey.

\subsection{Methods and Analyses}

We prepared capture sites ( $\mathrm{n}=20$ - 35/year; January-February) on both study areas each year by clearing and pre-baiting with cracked corn or multi-grain livestock feed. Rocket nets were placed at sites after confirming use by female turkeys. We netted turkeys from January to early March each year [12]. Once netted, we secured turkeys, placed each into cardboard boxes specifically designed for wild turkeys, and fitted each captured female with standard numbered metal leg bands and a backpack-style radio transmitter with mortality switch (ATS transmitters, model A1540, 69 - 80 g; weighing $<3.5 \%$ of birds body weight). We aged, weighed, and released turkeys within 45 minutes of capture at the capture location.

We located radioed females remotely by triangulation from $\geq 3$ distinct telemetry stations within 15 minutes to reduce error associated with long-distance movements of the radioed bird [13] [14] using hand-held radio receivers and three element Yagi antennae from pre-established telemetry stations $(n=100-250$ depending upon site and year) using the peak method [14]. We entered recorded azimuths into the program Location 
of a Signal [15] to map the estimated location of females. Birds were located $\geq 3$ times weekly from early March until 15 July each year. When observations indicated a female had initiated a nest and begun incubation (i.e., was found repeatedly in the same location), we recorded a nesting attempt if it could be confirmed by homing on the nesting bird [16]. Active nests were monitored $\geq 1$ times daily via telemetry, and when the female was away from the nest, we confirmed the status of the nest visually. We considered nests that hatched $\geq 1$ egg successful [16].

Once nest fate was determined, we measured nest site habitat characteristics at microhabitat (i.e., the area within $7 \mathrm{~m}$ of the nest) and patch levels (i.e., the area within 28 $\mathrm{m}$ the nest; Table 1 ). After recording the characteristics at the nest site, we immediately recorded the same characteristics in a similar plot located at a random distance and direction from the nest within the same habitat patch [11] for both microhabitat and patch levels.

To characterize microhabitat, we established a $7 \mathrm{~m}$ radius plot centered on the nest. Within the plot, three $7 \mathrm{~m}$ transects were established radiating out from the nest and separated by $120^{\circ}$. We measured basal area $\left(\mathrm{m}^{2} / \mathrm{ha}\right)$ of hardwood, conifer, and palm species $\geq 11.43 \mathrm{~cm}$ diameter-at-breast-height ( $\mathrm{dbh}$ ) surrounding the nest using a standard 10-BAF prism [17] [18] [19]. Stem density (no./ha) of tree species $\geq 2.54 \mathrm{~cm} \mathrm{dbh}$ within the plot were tallied as hardwood, conifer, or palm species. Canopy cover of saw palmetto at $1.5 \mathrm{~m}$ above the ground was estimated using the line-intercept method along each transect (\%; [19]). From the nest at a height of $1.7 \mathrm{~m}$, we visually estimated lateral cover (visual obstruction) by determining total cover (\%) of a $36 \mathrm{~cm} \times 90 \mathrm{~cm}$ cover board placed at three equally spaced points (i.e., $120^{\circ}$ apart) $7 \mathrm{~m}$ from the nest [19]. To classify cover, we recorded cover estimates as one of six cover classes: $1=0 \%$ $3 \%, 2=\geq 4 \%-12 \%, 3=\geq 13 \%-25 \%, 4=\geq 26 \%-50 \%, 5=\geq 51 \%-75 \%$, and $6=\geq 76 \%-$ $100 \%$. On each transect, we recorded height of the tallest shrubs (including shrubs and trees $<2.54 \mathrm{~cm} \mathrm{dbh;} \mathrm{[19])} \mathrm{intersecting} \mathrm{the} \mathrm{transect.}$

Table 1. Florida wild turkey nest habitat variables at microhabitat (within $7 \mathrm{~m}$ of nest) and patch (within 28 m of nest) levels, Florida, 2008-2010.

\begin{tabular}{|c|c|}
\hline Variable (Abbreviation) & Description \\
\hline Conifer basal area (BAC) & Conifer species basal area $\left(\mathrm{m}^{2} / \mathrm{ha}\right)$ \\
\hline Hardwood basal area (BAH) & Hardwood species basal area $\left(\mathrm{m}^{2} / \mathrm{ha}\right)$ \\
\hline Palm basal area (BAP) & Palm species basal area $\left(\mathrm{m}^{2} / \mathrm{ha}\right)$ \\
\hline Total basal area (BAT) & Total basal area $\left(\mathrm{m}^{2} / \mathrm{ha}\right)$ \\
\hline Conifer stems (STC) & Conifer species stem density (number/ha) \\
\hline Hardwood stems (STH) & Hardwood species stem density (number/ha) \\
\hline Palm stems (STP) & Palm species stem density (number/ha) \\
\hline Total stems (STT) & Total stem density (number/ha) \\
\hline Saw palmetto cover (SC) & Saw palmetto cover $(\%)$ \\
\hline Visual obstruction (VO) & Visual obstruction (\%) \\
\hline Shrub height (SHT) & Shrub height $(\mathrm{cm})$ \\
\hline
\end{tabular}


To characterize vegetation at the patch level, we established a $28 \mathrm{~m}$ radius plot centered on the nest. Within the plot, three $28 \mathrm{~m}$ transects were established radiating out from the nest and separated by $120^{\circ}$. We established a $7 \mathrm{~m}$ radius subplot on the nest and $21 \mathrm{~m}$ from the nest on each transect (four subplots total). Within each subplot, basal area, stem density, and lateral cover were determined as described for microhabitat. Along each $28 \mathrm{~m}$ transect, saw palmetto cover and shrub height were quantified as described for microhabitat.

To understand female Florida wild turkey nest habitat selection and how habitat affected nest success, we used logistic regression in an Information-Theoretical framework [20]. We used case-control logistic regression to compare habitat variables within nest plots and their associated random plots at the microhabitat and patch levels. Based on prior knowledge, field experience, and study objectives, we created a priori models featuring combinations of variables at both microhabitat and patch levels (Table 1). Individual models were limited to 3 predictor variables to reduce the likelihood of overfitting. We examined Akaike's Information Criterion corrected for small sample size $\left(\mathrm{AIC}_{\mathrm{c}}\right)$, distance from the lowest $\mathrm{AIC}_{\mathrm{c}}\left(\Delta \mathrm{AIC}_{\mathrm{c}}\right)$, and Akaike weights $\left(w_{i}\right)$ for models with different combinations of predictor variables, and considered models with $\Delta \mathrm{AIC}_{\mathrm{c}}$ $\leq 2$ supported [21]. Where multiple models were supported, we used model averaging to increase precision of inference, and when $85 \%$ confidence intervals (CI) for modelaveraged variables overlapped with zero, we considered them to have a weak effect on the dependent variable and be uninformative [22]. When an $85 \%$ CI was $>0$, we indicate that the variable was selected and $<0$ avoided.

We used logistic regression, following methods described above for selection, to compare habitat of successful and unsuccessful nests at the microhabitat and patch levels. For brevity and clarity, we only present results on supported models. A complete list of models considered can be found in [2].

\section{Results}

We discovered 67 nests (27 successful) of radioed females. The leading cause of nest failure was depredation $(n=24)$, though nests also failed due to predation of the adult female on the nest $(n=8)$ and abandonment (total $n=7$; due to habitat management [ $\mathrm{n}=3$; prescribed fire and logging], due to observer interference $[\mathrm{n}=1]$, and unknown cause $[\mathrm{n}=3])$. One nest was established near the study's terminus and not monitored to fate. We censored this nest and nests failing due to management or observer interference $(n=5)$ from all analyses because no data regarding habitat characteristics could be recorded and these nests failed due to artificial causes not dependent upon the adult females selection decisions.

At the microhabitat level, three models were supported, with increasing saw palmetto cover and palm stem density selected (Table 2 and Table 3 ). Five models were supported at the patch level, with increasing hardwood and conifer stem density avoided (Table 4 and Table 5).

At the microhabitat level, seven models examining habitat differences between successful 
Table 2. Supported models, number of variables (K), Akaike's Information Criterion corrected for small sample size $\left(\mathrm{AIC}_{c}\right)$, distance from the lowest $\mathrm{AIC}_{c}\left(\Delta \mathrm{AIC}_{c}\right)$, and model weights $\left(w_{i}\right)$ used to predict female Florida wild turkey nest microhabitat selection in Florida, 2008-2010.

\begin{tabular}{ccccc}
\hline Model $^{\mathrm{a}}$ & $\mathrm{K}$ & $\mathrm{AIC}_{\mathrm{c}}$ & $\Delta \mathrm{AIC}_{\mathrm{c}}$ & $W_{i}$ \\
\hline STP, STC, SC & 3 & 59.18 & 0.00 & 0.31 \\
STP, STH, SC & 3 & 59.29 & 0.11 & 0.29 \\
STP, SC & 2 & 59.52 & 0.34 & 0.26 \\
\hline
\end{tabular}

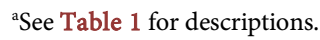

Table 3. Model-averaged parameter estimates and $85 \%$ confidence intervals (CI) for variables used in supported models to predict female Florida wild turkey nest microhabitat selection in Florida, USA, 2008-2010.

\begin{tabular}{cccc}
\hline & & \multicolumn{2}{c}{$85 \% \mathrm{CI}$} \\
\cline { 3 - 4 } Variable $^{\mathrm{a}}$ & Estimate & Lower & Upper \\
\cline { 3 - 4 } & & 0.001 & 0.487 \\
STP & 0.254 & -0.031 & 0.005 \\
STC & -0.014 & 0.024 & 0.094 \\
SC & 0.065 & -0.023 & 0.005 \\
STH & -0.010 & & \\
\hline
\end{tabular}

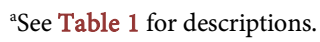

Table 4. Supported models, number of variables (K), Akaike's Information Criterion corrected for small sample size $\left(\mathrm{AIC}_{\mathrm{c}}\right)$, distance from the lowest $\mathrm{AIC}_{\mathrm{c}}\left(\Delta \mathrm{AIC}_{\mathrm{c}}\right)$, and model weights $\left(w_{i}\right)$ used to predict female Florida wild turkey nest patch habitat selection in Florida, 2008-2010.

\begin{tabular}{ccccc}
\hline Model $^{\mathrm{a}}$ & $\mathrm{K}$ & $\mathrm{AIC}_{\mathrm{c}}$ & $\Delta \mathrm{AIC}_{\mathrm{c}}$ & $w_{i}$ \\
\hline STP, STH & 2 & 70.63 & 0.00 & 0.23 \\
STP, STH, SC & 3 & 71.75 & 1.13 & 0.14 \\
STP, VO & 2 & 72.02 & 1.39 & 0.11 \\
STP & 1 & 72.12 & 1.49 & 0.11 \\
STP, STC, STH & 3 & 72.57 & 0.94 & 0.09 \\
\hline
\end{tabular}

${ }^{\text {a }}$ See Table 1 for descriptions.

Table 5. Model-averaged parameter estimates and $85 \%$ confidence intervals (CI) for variables used in supported models to predict female Florida wild turkey nest patch habitat selection in Florida, USA, 2008-2010.

\begin{tabular}{cccc}
\hline & & \multicolumn{2}{c}{$85 \% \mathrm{CI}$} \\
\cline { 3 - 4 } Variable $^{\mathrm{a}}$ & Estimate & Lower & Upper \\
\hline STP & 0.047 & -0.018 & 0.103 \\
STH & -0.002 & -0.003 & -0.001 \\
SC & -0.008 & -0.020 & 0.006 \\
VO & -0.016 & -0.035 & 0.005 \\
STC & -0.002 & -0.003 & -0.001 \\
\hline
\end{tabular}

${ }^{a}$ See Table 1 for descriptions. 
and unsuccessful nests were supported, with decreasing total and conifer basal area and increasing saw palmetto cover important to success (Table 6 and Table 7). Patch level nest success had three supported models, but included no informative individual variables (Table 8 and Table 9).

Table 6. Supported models, number of variables (K), Akaike's Information Criterion corrected for small sample size $\left(\mathrm{AIC}_{c}\right)$, distance from the lowest $\mathrm{AIC}_{c}\left(\Delta \mathrm{AIC}_{c}\right)$, and model weights $\left(w_{i}\right)$ used to predict Florida wild turkey nest success at the microhabitat level in Florida, 2008-2010.

\begin{tabular}{ccccc}
\hline Model $^{\mathrm{a}}$ & $\mathrm{K}$ & $\mathrm{AIC}_{\mathrm{c}}$ & $\Delta \mathrm{AIC}_{\mathrm{c}}$ & $W_{i}$ \\
\hline BAT & 1 & 82.66 & 0.00 & 0.12 \\
BAC, SC & 2 & 82.95 & 0.30 & 0.10 \\
BAT, SC & 2 & 83.04 & 0.38 & 0.09 \\
STP, BAC & 2 & 83.19 & 0.53 & 0.09 \\
STP, BAT & 2 & 83.44 & 0.78 & 0.08 \\
BAT, STT & 2 & 84.01 & 1.35 & 0.05 \\
STP, STC & 2 & 84.15 & 1.50 & 0.05 \\
\hline
\end{tabular}

${ }^{\mathrm{a} S e e}$ Table 1 for descriptions.

Table 7. Model-averaged parameter estimates and $85 \%$ confidence intervals (CI) for variables used in supported models to predict Florida wild turkey nest success at the microhabitat level in Florida, 2008-2010.

\begin{tabular}{cccc}
\hline & & \multicolumn{2}{c}{$85 \% \mathrm{CI}$} \\
\cline { 3 - 4 } Variable $^{\mathrm{a}}$ & Estimate & Lower & Upper \\
\cline { 3 - 4 } BAT & -0.103 & -0.132 & -0.001 \\
BAC & -0.192 & -0.230 & -0.009 \\
SC & 0.013 & 0.001 & 0.026 \\
STP & -0.636 & $--^{\mathrm{b}}$ & $--^{\mathrm{b}}$ \\
STT & -0.001 & -0.003 & 0.001 \\
STC & -0.004 & -0.008 & 0.001 \\
\hline
\end{tabular}

${ }^{\text {aS }}$ ee Table 1 for descriptions. ${ }^{b}$ Did not converge.

Table 8. Supported models, number of variables $(K)$, Akaike's Information Criterion corrected for small sample size $\left(\mathrm{AIC}_{\mathrm{c}}\right)$, distance from the lowest $\mathrm{AIC}_{\mathrm{c}}\left(\Delta \mathrm{AIC}_{\mathrm{c}}\right)$, and model weights $\left(w_{i}\right)$ used to predict Florida wild turkey nest success at the nest patch level in Florida, 2008-2010.

\begin{tabular}{ccccc}
\hline Model $^{\mathrm{a}}$ & $\mathrm{K}$ & $\mathrm{AIC}_{\mathrm{c}}$ & $\Delta \mathrm{AIC}_{\mathrm{c}}$ & $w_{i}$ \\
\hline BAP & 1 & 83.63 & 0.00 & 0.22 \\
BAT & 1 & 85.44 & 1.81 & 0.10 \\
STP, BAP & 2 & 85.62 & 1.99 & 0.08
\end{tabular}

${ }^{\mathrm{a}} \mathrm{See}$ Table 1 for descriptions. 
Table 9. Model-averaged parameter estimates and $85 \%$ confidence intervals (CI) for variables used in supported models to predict Florida wild turkey nest success at the nest patch level in Florida, 2008-2010.

\begin{tabular}{cccc}
\hline & & \multicolumn{2}{c}{$85 \% \mathrm{CI}$} \\
\cline { 3 - 4 } Variable $^{\mathrm{a}}$ & Estimate & Lower & Upper \\
\cline { 3 - 4 } & & -3.362 & 0.552 \\
BAP & -1.561 & -0.213 & 0.018 \\
BAT & -0.109 & -0.006 & 0.009 \\
STP & 0.002 & & \\
\hline
\end{tabular}

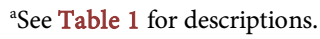

\section{Discussion}

Turkey nests failed for several reasons, but the most significant causes of failure were nest depredation or predation of the incubating female. Many have cited depredation or predation of the incubating adult as the leading causes of turkey nest failure, which may limit populations (e.g., [4] [8] [10] [23] [24]). Others such as [8] [9] [25] have reported habitat effects on nest success, and suggested that depredation may influence selection of nest sites by causing avoidance of certain habitats or habitat features. However, no such data exists for Florida wild turkeys.

Female Florida wild turkey microhabitat selection was for the presence of dense lateral cover in the form of shrubs. This manifested primarily in increased saw palmetto cover and palm stem density. Other researchers have also observed thick vegetation and saw palmetto at Florida wild turkey nests [4] [5] [26]. Females selected for greater levels of saw palmetto cover most likely to aid in concealing incubating birds as it can provide significant lateral cover. Saw palmetto also provides adult females with cover overhead, which reduces the probability of detection by avian predators [27] [28] [29], and may function to shade birds, decreasing nest temperatures. Our finding that successful nests at the microhabitat level had greater saw palmetto cover compared to unsuccessful nests, supports this conclusion. Findings for other wild turkey subspecies corroborate the importance or presence of dense cover featuring low shrubs and slash at nest sites and more open overstory canopies (e.g., [30]-[37]). Additionally, females preferred areas with higher densities of palm stems, which can also provide a great degree of lateral and overhead cover through standing vegetation and associated litter, decreasing predator efficiency by providing visual, auditory, and olfactory obstruction at nest sites [25] [38] [39] [40] [41]. Dense cover such as this may also provide greater numbers of locations where birds could establish nests, decreasing predator efficiency by making predators search in more areas to find nests. Reference [42] reported similar findings, with female eastern wild turkeys selecting for more stems near the nest site. However, compared to unsuccessful nests, successful nests at the microhabitat level in our study had lower total and conifer basal area.

At the patch level, females avoided areas with increasing hardwood and conifer stem densities. The dense cover selected at nest sites may conceal birds well, but it may not 
allow adult females to move easily or survey surrounding areas. Therefore, birds may choose to have more open habitats adjacent to nest sites. While models were supported assessing habitat differences between successful and unsuccessful nests at the patch lev$\mathrm{el}$, no individual habitat variables informed those differences. Other research has found similar results for nesting birds, suggesting that they prefer to be concealed on the nest, while being able to survey the area for threats when coming from and going to the nest (e.g., [25] [43] [44]). Additionally, though species such as saw palmetto afford dense understory cover to conceal adult females while nesting, it inhibits growth of other vegetation used for foraging by wild turkeys (e.g., [3] [45]). By selecting for patches of dense cover within more open habitats, birds may be selecting for areas with greater food potential nearby. And when they must leave the nest to forage, they do not have to travel far, and while foraging, they can readily see threats around them due to the reduced levels of lateral and overhead cover. Foraging in more open habitat such as this may decrease the risk of predation [4]. Moreover, when adult females are successful, newly hatched poults do not have to travel far to reach areas suitable for foraging [7] [46].

\section{Conclusion}

Female Florida turkeys selected for dense cover at the immediate nest site and more open habitats surrounding the nest. This selection may provide concealment at the nest site and habitat structure suitable for surveying areas surrounding the nest, facilitating nest site ingress and egress and foraging and brooding nearby. In some areas of Florida where saw palmetto dominates, shrub removal may be necessary to maintain appropriate overall habitat conditions [45] [47]. However, this study demonstrates its benefits to female Florida wild turkey nest site selection and success. Clumps of saw palmetto should be allowed to remain throughout habitats to aid in concealing incubating hens and possibly increasing the area that predators must search to find nests, while kept in low enough densities that turkeys can easily move and see through the area.

\section{Acknowledgements}

Financial and technical support was provided by the Florida Fish and Wildlife Conservation Commission, University of Florida, and University of Florida Foundation. Methods followed appropriate animal care and use protocols (e.g., AOU Ad Hoc Committee on Use of Wild Birds in Research 1988) and were approved by the University of Florida/IFAS Non-Regulatory Animal Research Committee (001-07WEC).

\section{References}

[1] Williams Jr., L.E. (2006) Wild Turkey Hunting and Management. Real Turkey Publishers, Cedar Key.

[2] Olson, J.M. (2011) Florida Wild Turkey Nest Site Selection and Nest Success across Multiple Scales. MS Thesis, University of Florida, Gainesville.

[3] Williams Jr., L.E. and Austin, D.H. (1988) Studies of the Wild Turkey in Florida. Technical 
Bulletin 10, University of Florida Press, Gainesville.

[4] Williams Jr., L.E. (1991) Managing for Wild Turkeys in Florida. Real Turkey Publishers, Gainesville.

[5] Dickson, J.G., Ed. (1992) The Wild Turkey: Biology and Management. Stackpole Books, Harrisburg.

[6] Johnson, D.H. (1980) The Comparison of Usage and Availability Measurements for Evaluating Resource Preference. Ecology, 61, 65-71. http://dx.doi.org/10.2307/1937156

[7] Lazarus, J.E. and Porter, W.F. (1985) Nest Habitat Selection by Wild Turkeys in Minnesota. Proceedings of the National Wild Turkey Symposium, Vol. 5, National Wildlife Turkey Federation, Edgefield, 67-81.

[8] Thogmartin, W.E. (1999) Landscape Attributes and Nest-Site Selection in Wild Turkeys. The Auk, 116, 912-923. http://dx.doi.org/10.2307/4089671

[9] Seiss, R.S., Phalen, P.S. and Hurst, G.A. (1990) Wild Turkey Nesting Habitat and Success Rates. Proceedings of the National Wild Turkey Symposium, Vol. 6, National Wildlife Turkey Federation, Edgefield, 18-24.

[10] Roberts, S.D. and Porter, W.F. (1996) Importance of Demographic Parameters to Annual Changes in Wild Turkey Abundance. Proceedings of the National Wild Turkey Symposium, Vol. 7, National Wildlife Turkey Federation, Edgefield, 15-20.

[11] Florida Natural Areas Inventory (2010) Guide to the Natural Communities of Florida: 2010 Edition. Florida Natural Areas Inventory, Tallahassee.

[12] Bailey, W., Bennett, D., Gore, H., Pack, J., Simpson, R. and Wright, G. (1980) Basic Considerations and General Recommendations for Trapping Wild Turkeys. Proceedings of the National Wild Turkey Symposium, Vol. 4, National Wildlife Turkey Federation, Edgefield, 251-261.

[13] White, G.C. and Garrott, R.A. (1990) Analysis of Wildlife Radio Tracking Data. Harcourt Brace Jovanovich, New York.

[14] Fuller, M.R., Millspaugh, J.J., Church, K.E. and Kenward, R.E. (2005) Wildlife Radiotelemetry. In: Braun, C.E., Ed., Techniques for Wildlife Investigations and Management, 6th Edition, The Wildlife Society, Bethesda, 377-417.

[15] Ecological Software Solutions (2010) Location of a Signal, Version 3.0.4. Ecological Software Solutions, Urnäsch.

[16] Tirpak, J.M., Giuliano, W.M., Miller, C.A., Allen, T.J. and Bittner, S. (2006) Ruffed Grouse Nest Success and Habitat Selection in the Central and Southern Appalachians. The Journal of Wildlife Management, 70, 138-144. http://dx.doi.org/10.2193/0022-541X(2006)70[138:RGNSAH]2.0.CO;2

[17] Krebs, C.J. (1999) Ecological Methodology. Addison-Wesley Educational Publishers, Inc., Menlo Park.

[18] Sparks, J.C., Masters, R.E. and Payton, M.E. (2002) Comparative Evaluation of Accuracy and Efficiency of Six Forest Sampling Methods. Proceedings of the Oklahoma Academy of Science, Vol. 82, Oklahoma Academy of Science, Stillwater, 49-56.

[19] Higgins, K.F., Jenkins, K.J., Clambey, G.K., Uresk, D.W., Naugle, D.E., Norland, J.E. and Barker, W.T. (2005) Vegetation Sampling and Measurement. In: Braun, C.E., Ed., Techniques for Wildlife Investigations and Management, 6th Edition, The Wildlife Society, Bethesda, 524-553.

[20] Burnham, K.P. and Anderson, D.R. (2002) Model Selection and Inference: A Practical Information-Theoretic Approach. 2nd Edition, Springer-Verlag, New York. 
http://dx.doi.org/10.1007/b97636

[21] Burnham, K.P. and Anderson, D.R. (1998) Model Selection and Inference: A Practical Information-Theoretic Approach. Springer-Verlag, New York.

http://dx.doi.org/10.1007/978-1-4757-2917-7

[22] Arnold, T.W. (2010) Uninformative Parameters and Model Selection Using Akaike's Information Criterion. The Journal of Wildlife Management, 74, 1175-1178. http://dx.doi.org/10.2193/2009-367

[23] Byrne, M.E. and Chamberlain, M.J. (2013) Nesting Ecology of Wild Turkeys in a Bottomland Hardwood Forest. The American Midland Naturalist, 170, 95-110. http://dx.doi.org/10.1674/0003-0031-170.1.95

[24] Little, A.R., Streich, M.M., Chamberlain, M.J., Conner, L.M. and Warren R.J. (2014) Eastern Wild Turkey Reproductive Ecology in Frequently-Burned Longleaf Pine Savannas. Forest Ecology and Management, 331, 180-187. http://dx.doi.org/10.1016/j.foreco.2014.07.030

[25] Badyaev, A.V. (1995) Nesting Habitat and Nesting Success of Eastern Wild Turkeys in the Arkansas Ozark Highlands. The Condor, 97, 221-232. http://dx.doi.org/10.2307/1368998

[26] Williams Jr., L.E., Austin, D.H., Eichholz, N.F., Peoples, T.E. and Phillips, R.W. (1968) A Study of Nesting Turkeys in Southern Florida. Proceedings of the Annual Conference of Southeastern Association of Fish and Wildlife Agencies, Vol. 22, Southeastern Association of Fish and Wildlife Agencies, Jackson, 16-30.

[27] Lehman, C.P., Flake, L.D. and Thompson, D.J. (2003) Comparison of Microhabitat Conditions at Nest Sites Between Eastern (Meleagris gallopavo silvestris) and Rio Grande Wild Turkeys (M. g. intermedia) in Northeastern South Dakota. The American Midland Naturalist, 149, 192-200.

http://dx.doi.org/10.1674/0003-0031(2003)149[0192:COMCAN]2.0.CO;2

[28] Nguyen, L.P., Hamr, J. and Parker, G.H. (2004) Nest Site Characteristics of Eastern Wild Turkeys in Central Ontario. Northeastern Naturalist, 11, 255-260. http://dx.doi.org/10.1656/1092-6194(2004)011[0255:NSCOEW]2.0.CO;2

[29] Lehman, C.P., Rumble, M.A., Flake, L.D. and Thompson, D.J. (2006) Merriam's Turkey Nest Survival and Factors Affecting Nest Predation by Mammals. The Journal of Wildlife Management, 72, 1765-1774. http://dx.doi.org/10.2193/2007-519

[30] Lutz, S.R. and Crawford, J.A. (1987) Reproductive Success and Nesting Habitat of Merriam's Wild Turkeys in Oregon. The Journal of Wildlife Management, 51, 783-787. http://dx.doi.org/10.2307/3801740

[31] Schmutz, J.A., Braun, C.E. and Andelt, W.F. (1989) Nest Habitat Use of Rio Grande Wild Turkeys. Wilson Bulletin, 101, 591-598.

[32] Day, K.S., Flake, L.D. and Tucker, W.L. (1991) Characteristics of Wild Turkey Nest Sites in a Mixed-Grass Prairie-Oak-Woodland Mosaic in the Northern Great Plain, South Dakota. Canadian Journal of Zoology, 69, 2840-2845. http://dx.doi.org/10.1139/z91-400

[33] Eichler, B.G. and Whiting Jr., R.M. (2004) Nesting Habitat of Eastern Wild Turkeys in East Texas. Texas Journal of Science, 56, 405-414.

[34] Palmer, W.E., Hurst, G.A., Godwin, K.D. and Miller, D.A. (1996) Effects of Prescribed Burning on Wild Turkeys. Transactions of the North American Wildlife and Natural Resources Conference, Vol. 61, Wildlife Management Institute, Washington DC, 228-236.

[35] Fuller, A.K., Spohr, S.M., Harrison, D.J. and Servello, F.A. (2013) Nest Survival of Wild Turkeys Meleagris gallopavo silvestris in a Mixed-Use Landscape: Influences at Nest-Site and Patch Scales. Wildlife Biology, 19, 138-146. http://dx.doi.org/10.2981/11-121 
[36] Streich, M.M., Little, A.R., Chamberlain, M.J., Conner, L.M. and Warren, R.J. (2015) Habitat Characteristics of Eastern Wild Turkey Nest and Ground-Roost Sites in 2 Longleaf Pine Forests. Journal of the Southeastern Association of Fish and Wildlife Agencies, 2, 164-170.

[37] Little, A.R., Nibbelink, N.P., Chamberlain, M.J., Conner, L.M. and Warren, R.J. (2016) Eastern Wild Turkey Nest Site Selection in Two Frequently Burned Pine Savannas. Ecological Processes, 5, 4. http://dx.doi.org/10.1186/s13717-016-0051-7

[38] Bowman, G.B. and Harris, L.D. (1980) Effect of Spatial Heterogeneity on Ground-Nest Depredation. The Journal of Wildlife Management, 44, 806-813. http://dx.doi.org/10.2307/3808308

[39] Redmond, G.W., Keppie, D.M. and Herzog, P.W. (1982) Vegetative Structure, Concealment, and Success at Nests of Two Races of Spruce Grouse. Canadian Journal of Zoology, 60, 670-675. http://dx.doi.org/10.1139/z82-096

[40] Crabtree, R.L., Broome, L.S. and Wolfe, M.L. (1989) Effects of Habitat Characteristics on Gadwall Nest Predators and Nest-Site Selection. The Journal of Wildlife Management, 53, 129-137. http://dx.doi.org/10.2307/3801319

[41] Shields, R.D. and Flake, L.D. (2004) Nest Site Characteristics of Eastern Wild Turkey in Northeastern South Dakota. Prairie Naturalist, 36, 161-175.

[42] Thomas, G.E. and Litvaitis, J.A. (1993) Nesting Ecology of Wild Turkeys in New Hampshire. Transactions of the Northeast Section of the Wildlife Society, Vol. 50, Northeast Section of the Wildlife Society, Bethesda, 119-126.

[43] Logan, T.H. (1973) Seasonal Behavior of Rio Grande Wild Turkeys in Western Oklahoma. Proceedings of the Annual Conference of Southeastern Association of Fish and Wildlife Agencies, Vol. 27, Southeastern Association of Fish and Wildlife Agencies, Jackson, 74-91.

[44] Speake, D.W., Lynch, T.E., Fleming, W.J., Wright, G.A. and Hamrick, W.J. (1975) Habitat Use and Seasonal Movements of Wild Turkeys in the Southeast. Proceedings of the National Wild Turkey Symposium, Vol. 3, National Wildlife Turkey Federation, Edgefield, 122-129.

[45] Willcox, E.V. and Giuliano, W.M. (2010) Seasonal Effects of Prescribed Burning and Roller Chopping on Saw Palmetto in Flatwoods. Forest Ecology and Management, 259, 1580 1585. http://dx.doi.org/10.1016/j.foreco.2010.01.034

[46] Vander Haegen, W.M., Sayre, M.W. and Cardoza, J.E. (1991) Nesting and Brood-Rearing Habitat Use in a Northern Wild Turkey Population. Transactions of the Northeast Section of the Wildlife Society, Vol. 48, Northeast Section of the Wildlife Society, Bethesda, 113119.

[47] Kilburg, E.L., Moorman, C.E., DePerno, C.S., Cobb, D. and Harper, C.A. (2014) Wild Turkey Nest Survival and Nest-Site Selection in the Presence of Growing-Season Prescribed Fire. The Journal of Wildlife Management, 78, 1033-1039.

http://dx.doi.org/10.1002/jwmg.751 
Submit or recommend next manuscript to SCIRP and we will provide best service for you:

Accepting pre-submission inquiries through Email, Facebook, LinkedIn, Twitter, etc. A wide selection of journals (inclusive of 9 subjects, more than 200 journals)

Providing 24-hour high-quality service

User-friendly online submission system

Fair and swift peer-review system

Efficient typesetting and proofreading procedure

Display of the result of downloads and visits, as well as the number of cited articles

Maximum dissemination of your research work

Submit your manuscript at: http://papersubmission.scirp.org/

Or contact nr@scirp.org 